\title{
Degradability of Andean range forages in llamas and sheep
}

\author{
DIDIER GENIN AND MURIEL TICHIT
}

Authors are range scientist and graduate student, Institut Français de Recherche Scientifique pour le Développment en Coopération (ORSTOM), C.P. 9214, La Paz, Bolivia.

\begin{abstract}
In sacco dry matter degradability (DMD) of the most commonly consumed range forages by llamas and sheep in the arid highlands of Bolivia was measured during the wet and dry seasons to determine if llamas exhibit a higher digestive ability than sheep. Results showed that degradability of low quality forages (DMD below $60 \%$ in sheep) was 20 to $30 \%$ higher for llamas than sheep, while no significant differences were found for highly digestible forages. There was a high correlation between DMD in llamas and sheep with a coefficient of determination of 0.96 . Parameters of degradation curves indicated that lamas did not have higher microbial activity than sheep, since there was no consistent difference in degradation rates of the studied forages. Nonetheless, significantly higher potential degradability and effective degradability found in this study suggested that the longer retention time in the forestomach of llamas may he responsible for higher digestibility of poor quality forages.
\end{abstract}

Key Words: in sacco disappearance, kinetics of degradation, arid highlands, Bolivia

Andean livestock herding systems frequently include both camelids and sheep, which are grazed together (Browman 1990, Tichit 1995). In the arid highlands of Bolivia, the association of llamas and sheep, and sometimes alpacas, has been characterized by Tichit and Genin 1997. Climatic conditions (annual rainfall of $300 \mathrm{~mm}$ and almost 300 days of frost per year) hinder agriculture and other livestock species like cattle and horses, which are present in more favourable Andean environments such as the subhumid Peruvian altiplano. The relative proportion of camelids within herds depends largely upon the nature of available forage resources and the overall size of the farms. Other factors such as particular historical transformations of communities, economic opportunities and socio-cultural patterns also influence herd structure. From an ecophysiological point of view, mixed herds of llamas and sheep allow for better utilization of the overall

This work was carried out within the Collaborative Research Program between the Bolivian Institut of Agropastoral Technology (IBTA) and the ORSTOM entitled "Dynamics of production systems in the Bolivian highlands". The authors wish to thank P. Abasto and D. Coca for technical assistance and Lita Buttolph and Roberto Quiroz for helpful comments on the manuscript.

Corresponding address: D. Genin, Clos ORSTOM, 05130 Tallard, FRANCE.

Manuscript accepted 5 Oct. 1996.

\section{Resúmen}

Se midió la degradabilidad in sacco (DMD) en llamas y ovinos de la materia seca de los principales forrajes nativos del altiplano árido de Bolivia, con el fin de comparar las capacidades digestivas de estas dos especies animales. Los resultados muestran que la DMD de los forrajes de baja calidad (DMD inferior a $60 \%$ en ovinos) es mayor en un 20 a $30 \%$ en llamas respecto a ovinos, mientras que no se observaron diferencieas significativas en el caso de forrajes altamente digeribles. Se encontró una alta correlación en las DMD entre llamas y ovinos $\left(r^{2}=0.96\right)$. Los parámetros de las curvas de degradación sugieren que las llamas no presentaron una actividad microbiana superior a la de los ovinos proque no hubo diferencias significativas en las tasas de degradación de los forrajes estudiados entre estas dos especies animales. Sin embargo, los valores significativamente superiores en la degradabilidad potencial y la degradabilidad efectiva encontrados en llamas indican que la superioridad de estos camélidos para digerir los forrajes de baja calidad se debe en primer lugar a un mayor tiempo de retención del alimento en el rumen.

available forage due to different grazing behavior (Pfister et al. 1989, San Martin 1987). In the arid highlands of Bolivia, Genin et al. (1994) showed that llamas consume significantly higher proportions of the dominant coarse bunchgrasses such as Festuca orthophylla Pilger and Stipa ichu (R \& P.) Kunth than sheep. Sheep seek more of the fine herbaceous plants growing under the shrub canopies. Though shrub foliage is abundant in these rangelands (Alzerreca and Lara 1988), shrubs represent less than 20\% of the dietary components of both llama and sheep.

Studies concerning the ability of these animal species to digest forage have been reviewed by San Martin and Bryant (1989) and Dulphy et al. (1994). They reported high discrepancies in digestion coefficients. These authors attribute these discrepancies to animal selectivity not taken into account in some experiments and to the quality of feed used. San Martin (1987) observed significantly greater digestion coefficients for llamas than sheep on low and medium quality reconstituted diets (less than $10 \% \mathrm{CP}$ and less than $2.8 \mathrm{Mcal}$ DE/kg DM) but did not find differences in high quality diets (15\% CP and $3.2 \mathrm{Mcal} \mathrm{DE} / \mathrm{kg} \mathrm{DM})$. In the Andean pastoral zone, animals graze exclusively on native range plants. Very few studies have emphasized the digestibility of range forages actually consumed by llamas and sheep in this 
region. Concerning the dominant coarse bunchgrasses of the Andean rangelands, Maiza and Cardozo (1992) reported a digestion coefficient for dry matter of $S$. ichu almost $20 \%$ greater in llamas than in sheep. Genin et al. (1994) found digestion coefficients of $F$. orthophylla significantly higher in llamas (54.2 and $41.3 \%$ during wet and dry seasons, respectively) than in sheep (41.4 and $39.4 \%$ during wet and dry seasons, respectively). No data are available concerning other classes of forages consumed by llamas and sheep in this area.

The purpose of this study was to compare in sacco dry matter degradability during wet and dry seasons and the kinetics of rumen degradation of range forages in llamas and sheep in the arid puna of Bolivia in order to determine if llamas can utilize more efficiently the dominant rangelands of this region.

\section{Material and Methods}

\section{In Sacco Dry Matter Degradation}

Three coarse bunchgrass species ( $F$. orthophylla, $F$. dolichophylla Presl., S. ichu), 3 fine grass species (Calamagrostis heterophylla (Wedd.) Pilger, Poa candamoana Pilger, Distichlis humilis Phil.), 4 shrubs (Adesmia spinosissima Meyen \& Vogel, Tetraglochin cristatum (Britton) Rothn, Parastrephia lepidophylla (Wedd.) Cabera, Baccharis incarum Wedd.) and 1 forb (Tarasa tenella (Cav.) Krapovickas), representing the most commonly consumed forages in the arid highlands of Bolivia (Genin et al 1994, Villca and Genin 1995), were collected during the wet (February) and dry (August) seasons. Parts of the plants normally selected by livestock were dried, and ground to pass a 2-mm Wiley mill screen. Samples of approximately $2 \mathrm{~g}$ were placed in $10 \times 15 \mathrm{~cm}$ nylon bags (50 $\mu \mathrm{m}$ mesh) for determining in sacco dry matter degradability (DMD), as described by Orskov et al. (1980). Six bags of each forage from each season were suspended in the rumen of 2 animals of each species for 48 hours, according to Michalet-Doreau et al. (1987). The experimental animals were four-year-old male llamas weighing $95 \mathrm{~kg}$ and two-year-old castrated sheep weighing $28 \mathrm{~kg}$ with rumen fistulas. They received ad libitum barley hay which fulfilled their nutritional requirements. Following removal from the rumen, bags were rinsed with water until effluent was clear, and frozen for storage. After drying the bags at $65^{\circ} \mathrm{C}$ for 48 hours, DMD was calculated as weight loss of material. Analyses of variance (6 repetitions $\times 2$ animals/species) was performed to compare, by forage and by season, the differences in degradability between llama and sheep. Simple linear regression was used to describe the relationship between degradability of forages in sheep and llamas.

\section{Degradation Kinetics}

Six forage species representing the 3 types of forages consumed by animals (coarse bunchgrasses $F$. orthophylla and $F$. dolichophylla; fine grass $C$. heterophylla; forb $T$. tenella; and shrubs $A$. spinosissima and $P$. lepidophylla) were collected in February (wet season). Six samples of each of these forages were incubated for 4, 8, 12, 24, 48, and 72 hours in rumens of llamas and sheep, using the procedures described above. Soluble dry matter losses (DMD at time 0) other than those due to microbial and enzymatic degradation were measured by placing a sample bag in water bath for 24 hours (Silva and Orskov 1988). The model by Orskov and McDonald (1979) was used in kinetics measurements to determine the plateau value of the different substrates and their rates of degradation:

$$
\mathrm{p}=\mathrm{a}+\mathrm{b}(1-\exp (-\mathrm{ct}))
$$

where: $p$ is the actual degradation after time $t ; a$ is the soluble fraction assumed to disappear instantly (intercept of the degradation at time zero); $b$ is the insoluble but potential degradable component of the feed; and $c$ is the rate constant at which $b$ is degraded.

Effective degradability (ED) was calculated assuming particulate passage rates of poor quality forages of 3.1 and $4.1 \%$ /hour for llamas and sheep, respectively (San Martin 1987), and the formula by Orskov and McDonald (1979):

$$
\mathrm{ED}=\mathrm{a}=(\mathrm{b}(\mathrm{c} /(\mathrm{c}+\mathrm{k})))
$$

where: $a, b$, and $c$ were the constants from Eq. 1 and $k$ was the particulate passage rate. The calculation for the DM degradation parameters was executed using the SAS program Proc NLIN (SAS, 1988).

\section{Results and Discussion}

\section{In Sacco DMD}

The in sacco dry matter digestibility (DMD) after 48 hours of incubation was higher in llama than in sheep for most forages, with differences varying from 1.1 to 13.7 degradability units (Table 1). Degradability values in llamas were approximately $1.25,1.1$, and 1.05 times those found in sheep for coarse bunchgrasses, forbs and fine grasses, and shrubs, respectively. The less degradable the forage, the greater was the difference between the 2 animal species. Significant differences were generally found for forages with DMD of roughly less than $60 \%$ in sheep. In the case of the Compositae shrubs $P$. lepidophylla and $B$. incarum, DMD values were very high and should be considered with caution because they may reflect high pulverization during milling with subsequent losses during washing.

There was a high correlation between DMD in llamas and sheep with a coefficient of determination $r^{2}$ of $0.96(p<0.01)$ (Fig. 1). Kayouli et al. (1991) compared degradability of mediterranean roughages in dromedary camels and sheep and found similar trends.

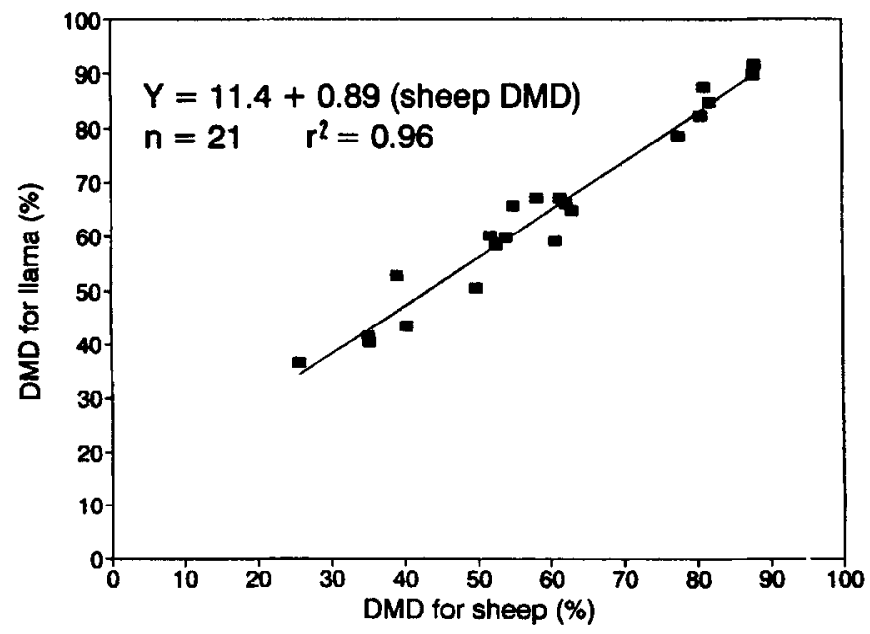

Fig. 1. Relationship between in sacco dry matter degradability in sheep and llamas. 
Table 1. Percentage in sacco dry matter degradability after $\mathbf{4 8}$ hours in lamas and sheep (Mean \pm S.E.) of dominant Andean range forages collected during wet and dry seasons.

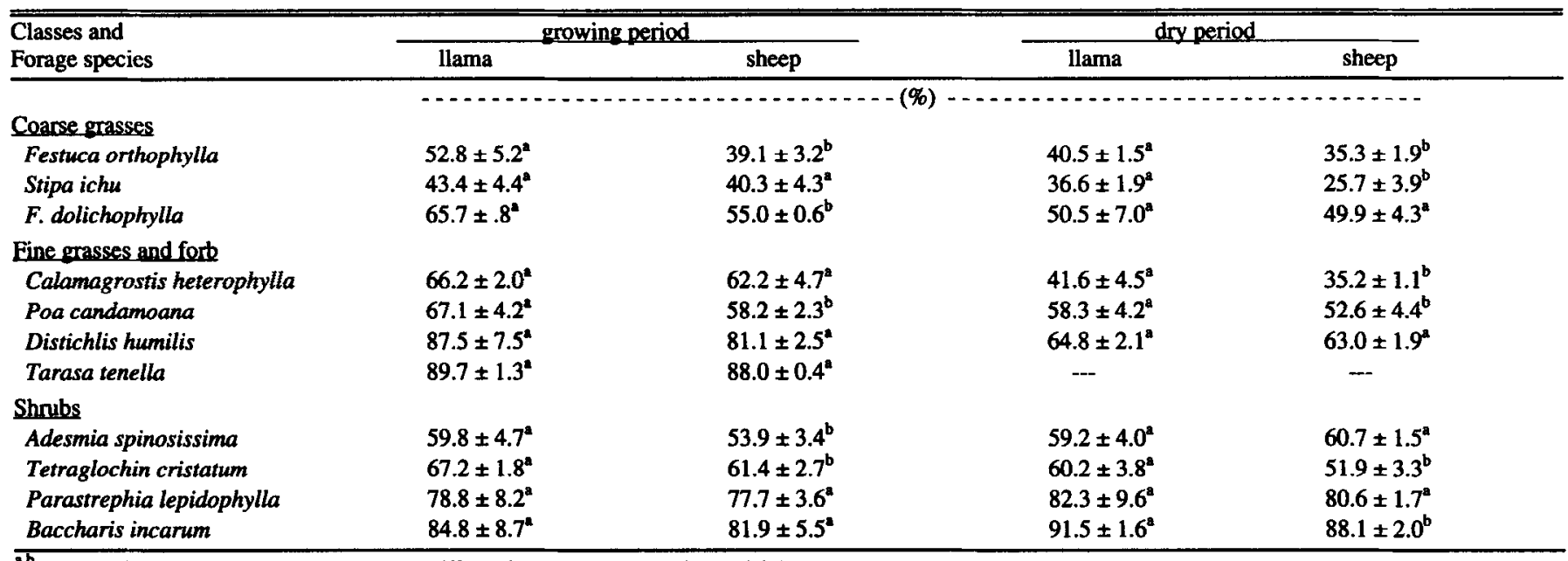

${ }^{n}$ Within period, means with different letters are different between animal species $(\mathbf{P}<0.01)$.

These authors reported differences in in sacco DMD between camels and sheep of more than 10 units for forage with a degradability of less than $50 \%$ in sheep, while there was little difference in degradability for high quality forages such as green ryegrass or ensiled sugar beet pulp. Cordesse et al. (1992) did not find any differences in digestibility between llamas and sheep utilizing lucerne hay and ammoniated wheat straw.

\section{Degradation Kinetics}

The degradation equation proposed by Oskov and McDonald (1979) provided a good fit of the data with coefficients of determination higher than 0.98 (Fig. 2, Table 2). This suggests that degradation patterns of forages proposed by these authors for ruminants are also relevant for pseudo-ruminants such as llamas.

The potential degradability (the factor $a+b$ of the model) was significantly higher in llamas than in sheep for $C$. heterophylla and $F$. orthophylla $(\mathrm{P}<0.01)$ and $A$. spinosissima $(\mathrm{P}<0.05)$. No differences were found for highly degradable forages (Table 2).

In contrast, degradation rates (factor $\mathrm{c}$ ) varied between llamas and sheep with no clearly defined pattern (Table 2). Values of $c$ varied from less than $0.03 \%$ hour $^{-1}$ for coarse bunchgrasses to more than $0.15 \%$ hour $^{-1}$ for the highly digestible $T$. tenella in both llamas and sheep. Degradation rates of coarse bunchgrasses were comparable to those of wheat straw found in sheep and goats, while degradation rates of $T$. tenella were superior to those of ryegrass (Flachowsky and Tiroke 1993). Degradation rates of shrubs were intermediate $\left(0.05\right.$ to $0.08 \%$ hour $\left.^{-1}\right)$.

These results suggest the importance of the transit time of the feed. Blaxter (1963) stated that maximal digestion occurs only if the passage of food is delayed so that the food is exposed to those sites where microbial action takes place. San Martin (1987), studying passage rates in llamas and sheep, found digesta retention time of low and medium quality rations in the first 2 compartments of the stomach of llamas of 29 hours (see San Martin and Bryant (1989) for a full description of the digestive system in South American camelids), whereas the retention time in the reticulo-rumen of sheep was 22 hours. On the basis of San Martin's estimates of particulate passage rate in the rumen (3.1 and $4.1 \%$ hour $^{-1}$ for low quality diets in llama and sheep, respectively), effective degradability of the studied forages was almost $30 \%$ higher in llamas than in sheep for forages of low degradability and less than $10 \%$ for highly degradable forages. In this study, the estimated effective degradability of $F$. orthophylla in the rumen conformed to 62 and $67 \%$ of the apparent digestibility found in vivo in llamas and sheep, respectively (Genin et al.

Table 2. Parameters of degradation curves (DMD- $a+b(1-(\exp (-\mathrm{et}))$, Orskov and McDonald 1979) of forages collected during growing season.

\begin{tabular}{|c|c|c|c|c|c|c|}
\hline \multirow[b]{2}{*}{ Forage species } & \multicolumn{2}{|c|}{ Potential degradability } & \multicolumn{2}{|c|}{ Degradation rate ${ }^{2}$} & \multicolumn{2}{|c|}{ Effective degradability ${ }^{3}$} \\
\hline & Sheep & Llamas & Sheep & Llamas & Sheep & Llamas \\
\hline $\begin{array}{l}\text { Coarse grasses } \\
\text { Festuca orthophylla } \\
F . \text { dolichophylla }\end{array}$ & $\begin{array}{l}47.4^{\mathrm{b4}} \\
81.3^{\mathrm{a}}\end{array}$ & $\begin{array}{l}71.4^{2} \\
83.9^{\star}\end{array}$ & $\begin{array}{l}0.025^{\mathrm{a}} \\
0.015^{\mathrm{b}}\end{array}$ & $0.013^{\mathrm{b}}$ & $\begin{array}{l}27.6^{b} \\
38.8^{b}\end{array}$ & $\begin{array}{l}33.5^{\mathrm{a}} \\
49.3^{\mathrm{a}}\end{array}$ \\
\hline $\begin{array}{l}\text { Eine grass and forb } \\
\text { Calamagrostis heterophylla } \\
\text { Tarasa tenella }\end{array}$ & $\begin{array}{l}58.2^{b} \\
88.6^{a}\end{array}$ & $\begin{array}{l}63.3^{2} \\
90.9^{n}\end{array}$ & $\begin{array}{l}0.024^{b} \\
0.107^{a}\end{array}$ & $\begin{array}{l}0.075^{\mathrm{a}} \\
0.144^{\mathrm{a}}\end{array}$ & $\begin{array}{l}32.5^{b} \\
70.6^{b}\end{array}$ & $\begin{array}{l}49.3^{\mathrm{a}} \\
77.3^{\mathrm{a}}\end{array}$ \\
\hline $\begin{array}{l}\text { Shrubs } \\
\text { Adesmia spinosissima } \\
\text { Parastrephia lepidophylla }\end{array}$ & $\begin{array}{l}61.1^{b} \\
79.5^{\mathrm{b}}\end{array}$ & $\begin{array}{l}65.8^{n} \\
84.6^{a}\end{array}$ & $\begin{array}{l}0.067^{\mathrm{a}} \\
0.079^{\mathrm{a}}\end{array}$ & $\begin{array}{l}0.048^{b} \\
0.054^{b}\end{array}$ & $\begin{array}{l}38.7^{b} \\
60.7^{a}\end{array}$ & $\begin{array}{l}48.5^{\mathrm{a}} \\
62.3^{\mathrm{a}}\end{array}$ \\
\hline
\end{tabular}

1 Potential degradability $=a+b ; a=$ soluble fraction $b=$ insoluble but potential degradable

2 Degradation rate $=\mathrm{c}$

${ }^{3}$ Effective degradability $=a+\left(b(c /(c+k))\right.$ where $k$ is passage rate $\left(3.1\right.$ and $4 / 1 \%$ hour ${ }^{-1}$ for llamas and sheep, respectively).

a. For each parameter, means followed by the same letter are not different between animal species $(\mathrm{P}<0.05)$. 

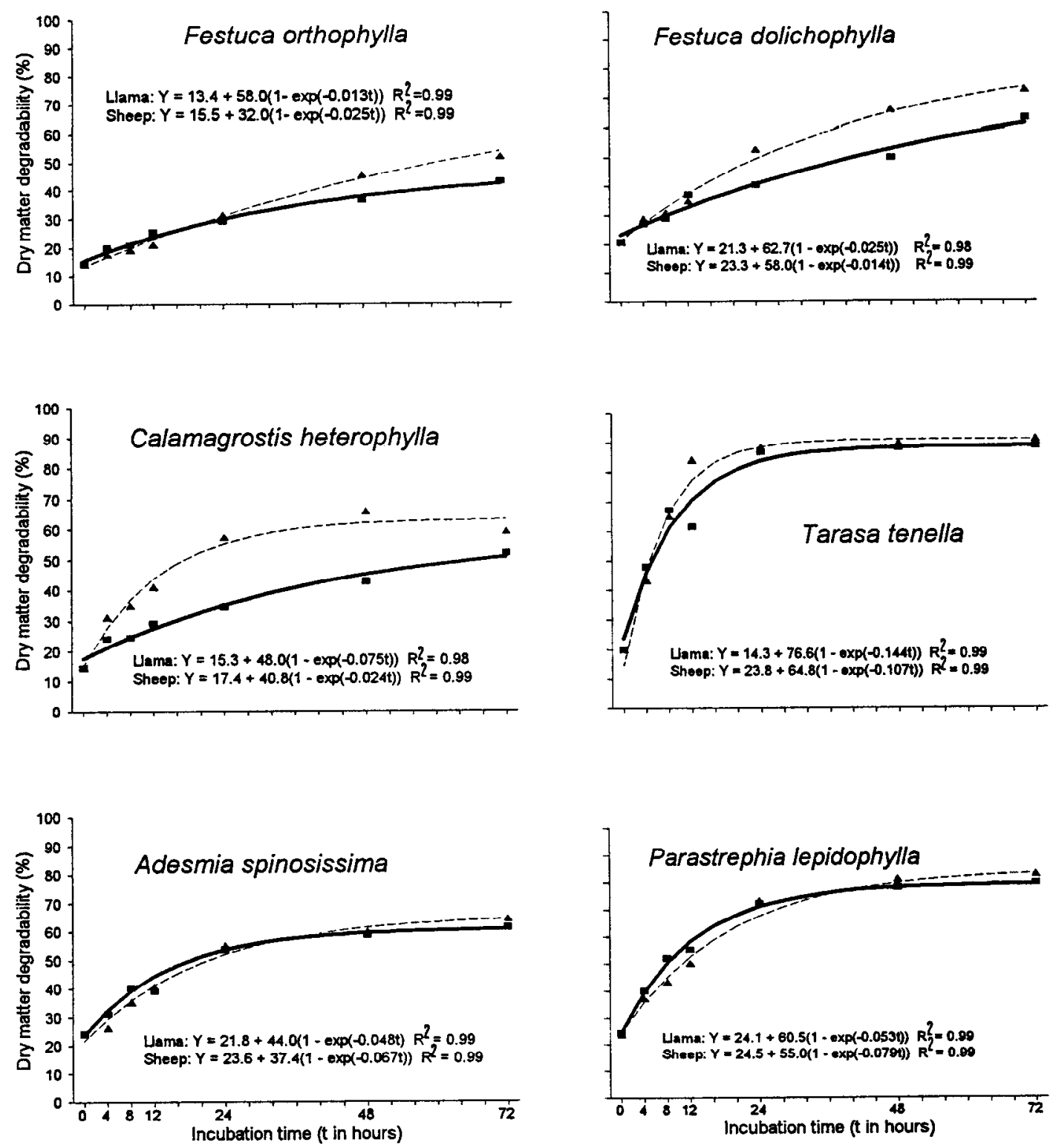

Fig. 2. Degradation curves of predominant Andean forages in llamas (dotted lines and triangles) and sheep (solid lines and squares). Values fitted to the equation $Y=a+b(1-\exp (-\mathrm{ct}))$ proposed by Orskov and McDonald (1979). Each symbol is the mean of 6 replicates.

1994). These proportions agree with those noted by Jarrige (1980) for forages of low digestibility (55 to $70 \%$ of the overall digestible OM effectively digested in the rumen). San Martin and Bryant (1989) suggested that longer retention time in rumen, associated with the peculiar morphology, histology and a higher motility of the forestomach confers a greater digestive efficiency of South American camelids, especially for low quality roughages. The enhanced ability to degrade low nitrogen feeds in llamas is also related to their capacity to maintain higher $\mathrm{NH}_{4}^{+}$ concentrations in their forestomach compared to sheep (Hinderer and Engelhardt 1975., Engelhardt and Schneider 1977). Further, Kayouli et al. (1993) showed a greater cellulolytic activity of the ruminal microbes in llamas than in sheep. However, further studies are required in which these mechanisms can be investigated simultaneously.

\section{Conclusions}

Due to their feeding behavior (Genin et al. 1994) and higher digestive capabilities resulting from slower transit time for particulate matter, llamas exhibited a greater adaptation than sheep to utilize the poor quality rangelands found in the arid Andean highlands, especially those dominated by coarse bunchgrasses which cover extensive areas of the region. Degradability coefficients for low quality Andean range forages found in this study were 20 to $30 \%$ high in llamas than in sheep. Although llamas may be more efficient grazers, sheep present some advantages such as a higher reproductive rate and a more ready market for their meat (Tichit 1995). These aspects could strongly influence the choice of herd composition in unpredictable environments (Mace and Houston 1989). At the farm level, llamas and sheep play complementary roles in the use of the available resources, in the products they supply, and in their capability to respond to household's needs. 
Raising these 2 species of livestock, combined in some cases with alpacas, is viewed as a sound strategy to spread different kinds of risks (i.e. drought, disease outbreaks, animal off-take in relation to reproductive capacities, and market price fluctuations).

\section{Literature Cited}

Alzerreca, H. and R. Lara. 1988. Evaluación de praderas nativas en el altiplano central y oeste del Departamento de Oruro. In: Mem. 1ra Reunión Nacional en Praderas Nativas de Bolivia. CORDEOR-PAC, Oruro, Bolivia. 3-11.

Blaxter, K.L. 1963. The energy metabolism of ruminants. London: Hutchinson Sci. and Tech., England.

Browman, D.L. 1990. High altitude camelid pastoralism of the Andes. p. 323-352. In: J.G. Galaty and D. Johnson (Eds.), the world of pastoralism: herding systems in comparative perspective. Guliford Press, New York, N.Y.

Cordesse, R., M. Inesta, and J.L. Gaubert. 1992. Intake and digestibility for four forages by llamas and sheep. Ann. Zootech. 41:70.

Dulphy, J.P., C. Dardillat, M. Jailler, and J.P. Jouany. 1994. Comparison of the intake and digestibility of different diets in llamas and sheep: a preliminary study. Ann. Zootech. 43:379-387.

Engelhardt, W. and W. Schneider. 1977. Energy and nitrogen metabolism in the llama. Anim. Res. and Develop. 5:68-72.

Flachowsky, G. and K. Tiroke. 1993. Influence of type of feeding and rumen incubation time on in sacco dry matter degradability of ryegrass, straw and concentrate in sheep and goat. Small Rumin. Res. 9:321-330.

Genin, D., Z. Villea, and P. Abasto. 1994. Diet selection and utilization by llama and sheep in a high altitude-arid rangeland of Bolivia. $J$. Range Manage. 47:245-248.

Hinderer, S. and W. Engelhardt. 1975. Urea metabolism in the llama. J. Comp. Physiol. 52:619-622.

Jarrige, R. (Ed.). 1980. Alimentation des ruminants. INRA, Paris, 2e édition. France.

Kayouli, C., J.P. Jouany, and J. Ben Amor. 1991. Comparison of microbial activity in the forestomachs of the dromedary and the sheep measured in vitro and in sacco on mediterranean roughages. Anim. Feed Sci. Tech. 33:237-245.

Kayouli, C., C. Dardillat, and J.P. Jouany. 1993. Comparative study of the muralytic activity of rumen microbes in situ in llamas and sheep. Ann. Zootech. 42:184.

Mace, R. and A. Houston. 1989. Pastoralist strategies for survival in unpredictable environments: a model of herd composition that maximizes household viability. Agr. Syst. 31:185-204.

Maiza, R. and A. Cardozn. 1992. Digestibilidad del ichu (Stipa ichu) en ovinos, llamas y vicuñas.pp 53-54. In: Mem. $X$ Reunión de Asociacion Boliviana de Producción Animal. La Paz, Bolivia, 18-20/10/1990. DANCHURCHAID-IBTA.

Michalet-Doreau, B., R. Vérité, and P. Chapoutot. 1987. Méthodologie de mesure de la dégradabilité de l'azote dans le rumen. Bull Tech. C.R.Z.V., Theix, France, 69:5-7.

Orskov, E.R. and I. McDonald. 1979. The estimation of protein degradability in the rumen from incubation measurements weighted according to rate of passage. J. Agric. Sci., Camb. 92:499-503.

Orskov, E.R., F.D. Hovell, and F. Mould. 1980. The use of nylon bag technique for the evaluation of feedstuffs. Trop. Anim. Prod. 5:195-213.

Pfister, J., F. San Martin, L. Rosales, D.V. Sisson, E. Flores, and F.C. Bryant. 1989. Grazing behaviour of llamas, alpacas and sheep in the Andes of Peru. Appl. Anim. Behav. Sci. 23:237-246.

SAS. 1988. Statistical Analysis System. SAS Users Guide. Version 6.03. SAS, Cary, N.C.

San Martin, F. 1987. Comparative selectivity and nutrition of South American camelids and sheep. Ph.D. Diss., Texas Tech. Univ., Lubbock, Tex.
San Martin, F. and F.C. Bryant. 1989. Nutrition of domesticated South American llamas and sheep. Small Rumin. Res. 2:191-216.

Silva, A.T. and E.R. Orskov. 1988. The effect of five different supplements on the degradation of straw in sheep given untreated barley straw. Anim. Feed Sci. Tech. 19:289-298.

Tichit, M. 1995. Diversidad de la actividad ganadera en las unidades de producción de Turco. p. 73-91. In: D. Genin, H.J. Picht, R. Lizarazu and T. Rodriguez (Eds.), Waira Pampa, un sistema pastoril camélidosovinos del altiplano árido boliviano. ORSTOM-CONPAC-IBTA, La Paz, Bolivia.

Tichit, M. and D. Genin. 1997. Factors affecting herd structure in mixed camelid-sheep pastoral system in the arid puna of Bolivia. J. Arid Environ. 35:167-180.

Villca, Z. and D. Genin. 1995. Uso comparativo de los recursos forrajeros por llamas y ovinos. I-Comportamiento alimenticio. p. 117-130. In: D. Genin, H.J. Picht, R. Lizarazu and T. Rodriguez (Eds.), Waira Pampa, un sistema pastoril camélidos-ovinos del altiplano árido boliviano. ORSTOM-CONPAC-IBTA, La Paz, Bolivia. 